\title{
Framework for Identifying Significant Environmental Impacts of Manufacturing and Service Operations
}

\author{
Samuel Famiyeh ${ }^{1}$ \\ ${ }^{1}$ GIMPA Business School, Ghana Institute of Management and Public Administration, Accra, Ghana \\ Correspondence: Samuel Famiyeh, GIMPA Business School, Ghana Institute of Management and Public \\ Administration, P.O. Box AH 50, Achimota, Accra, Ghana. Tel: 233-21-401-0681. E-mail: \\ sfamiyeh@gimpa.edu.gh
}

Received: May 8, 2014 Accepted: May 23, 2014 Online Published: July 1, 2014

doi:10.5539/jsd.v7n4p47 URL: http://dx.doi.org/10.5539/jsd.v7n4p47

\begin{abstract}
Every Environmental Management System [EMS] requires implementing organizations to identify the environmental aspects of their activities, products or services and clearly show how the identification of aspects that may have significant impacts on the environment are identified. However, procedures for the identification of aspects that are significant are not clearly defined. This paper adapt and modify the process used to identify project risks as a framework to develop a generic framework that can be used by all manufacturing and service organizations to identify the environmental aspects of their activities as well as those that are significant. The proposed framework outlines four key steps in identifying impacts that are significant, viz. Environmental Aspects Identification; Environmental Risk Assessment; Environmental Risk Profiling; and Environmental Risk Threshold Values.

The paper assesses the usability of the proposed framework by choosing one of the key activities in the mining sector as a test case. In this text case, the model identified dust as the most significant environmental impact in a typical hauling operation in a mine.
\end{abstract}

Keywords: aspects, environmental, inputs-outputs, risk, threshold, impacts

\section{Introduction}

The growing awareness of the interaction between human-designed systems and natural systems has led to increased pressure on industry and government to reduce activities that are harmful to the environment. According to Hamel and Prahalad (1994), organizations are slowly acknowledging the fact that sustainable business success and shareholder value cannot be achieved solely through maximizing short-term profit, but instead requires a longer term, responsible approach to the environment. Historically, governments have legislated and administrated for the environment using systems based on publicly-determined limits for pollution and subsequent inspection (Jesson \& Anderson, 1994). Initial business responses were therefore reactive to these external forces with activities centered on compliance, risk mitigation and remediation (Hunt \& Auster, 1990). Most environmental efforts have thus been remedial, "end-of-pipe" while preventative measures have been used only to a limited degree (Jesson \& Anderson, 1994). Reactive approach is fast becoming redundant as environmental problems are becoming complex and multidimensional (Jain \& Pant, 2010).

An Environmental Management System (EMS) provides a structured mechanism for evaluating the environmental aspects of operations, and facilitating the planning and implementation of management strategies to eliminate, or at least mitigate, adverse effects on the environment (Chavan, 2005). Every EMS requires an organization to identify the environmental aspects of its activities, products or services during the planning phase. These aspects are the elements of the organisation's activities, products, or services that can interact with the environment to create a change, been it positive or negative. The objective is to identify the aspects for all activities, products, and services in order to determine those that have or can have significant impact on the environment. Despite the introduction of this key requirement in the planning stage, no EMS standard clearly specifies how significant aspects should be identified. ISO 31000:2009, Risk management - Principles and guidelines, seems to provide some principles, framework and a process for managing risk in general, however was not specific to environmental management systems planning and implementation. This presents a huge deficiency for companies especially those in the developing economies in their effort to plan and implement an 
EMS that is accepted by regulators as well as international certification, hence, this paper aims at proposing a framework for the identification of environmental aspects as well as those that are significant based on a risk assessment criteria, a key technique used in the protection and management of the environment (Llewellyn, 1998; Slater \& Jones, 1999).

\subsection{Statement of the Problem}

Environmental Management System is one of the keys in achieving sustainability and can be described as a methodology by which organizations acting in a structured manner assess their operations to ensure that they are functioning in an environmentally legitimate way (Whitelaw, 1997). To facilitate and ensure an organization's compliance with its stated environmental policy, an EMS will commonly have mechanisms for: identifying environmental impacts; setting objectives and targets; developing operational and emergency procedures; assigning responsibilities and reporting structures; training; corrective and preventative actions; auditing and compliance monitoring; and management review and evaluation to achieve continual improvement (Chavan, 2005; Christini et al., 2004).

Every EMS requires an organization to identify the environmental aspects of its activities, products or services and clearly show how the identification of aspects that may have significant impacts on the environment are identified, however, for flexibility purposes, no EMS standard, not even ISO 14000 series clearly specify how significant impacts should be identified. This presents a huge deficiency for companies in their effort to plan and implement an EMS that is accepted by regulators as well as international certification, thus this paper aims at proposing a framework for the identification of environmental aspects as well as those that are significant to fill this huge GAP.

\subsection{Statement of Objectives}

Considering the importance of the identification of environmental aspects and significant impacts requirement in the planning and implementation of an Environmental Management System, this study aims at developing a framework that can be adapted by organizations for the identification of environmental aspects of their activities, products or services and show how the identification of aspects that may have significant impacts on the environment can be identified.

The remainder of this paper is structured as follows: the second section provides some literature on environmental management systems and the background of the international environmental management system standard, ISO 14001. The third section presents the research method. The proposed framework for the identification of environmental aspects and the identification of those that are significant as well as a real world application of this proposed framework in the mining sector as a text case are presented in the fourth section. Sections five and six present the discussions, conclusions and limitations, implications and directions for future research.

\section{Literature Review}

\subsection{Environmental Management Systems}

Concerns about effective management of the eco-system have intensified over the last decade (Gray, 2010). From international agencies to country and corporate leaders, the reduction in pollution has increasingly occupied centre-stage and continues to engender considerable debates about how to tackle this seemingly immense task (Porter \& van der Linde, 1995; Everett \& Neu, 2000; Rahaman et al., 2004).

Environmental management can be described as a methodology by which organizations acting in a structured manner assess their operations to ensure that they are functioning in an environmentally legitimate way (Whitelaw, 1997). An environmental management system is a management system that aims to encourage an organization to control its environmental impacts and reduce such impacts continuously. Steger (2000) defined an EMS as a "transparent and systematic process", known corporate-wide, with the purpose of prescribing and implementing environmental goals, policies and responsibilities, as well as a regular auditing of its elements.

Hannagan (1998) views that given the continued development of legislation, the growth of the sustainable indexes within the financial markets globally; environmental management clearly has to become an integral part of business strategy planning and policy setting, aligned to the core activities of an organization. In order to support the strategic planning and management of the environment, organizations will be increasingly compelled to adopt more formal reporting processes and systems to give greater transparency to their activities.

\subsection{International Environmental Management Standard}

Following the successful introduction of the ISO 9000 series of standards for manufacturers and service 
providers, a Strategic Advisory Group on the Environment ("SAGE") was established to assess the need for environmental management standards, and to recommend practical, best-practice options to develop the standards. During the 1990s SAGE recommended the development of a uniform international environmental management standard (EMS), to be known as the ISO 14000 series. The overall purpose of the standards is to assist companies and other organizations to develop their own proactive management systems, which take into account environmental issues and concerns, and which allow future benchmarking in relation to safe environmental practices (Fisher, 2003).

The ISO 14000 series of environmental management standards provide guidelines, principles and general supporting practices designed to help an organization develop and implement an environmental management system (Marimon et al., 2010). Specifically, the standards address: environmental assessments; environmental auditing; environmental performance evaluation; environmental labeling and declarations; lifecycle assessments; and integration of environmental issues into product design (ISO, 2004). Published on 1 September 1996, and then revised in 2004 (Blackman \& Guerrero, 2012), the ISO 14001 voluntary standard was developed as a basic framework defining the requirements of an EMS. It prescribes the requirements for implementing and maintaining an EMS. Additionally, it provides the opportunity for organizations to become certified through registered third-party auditors (Babakri et al., 2004; Potoski\&Prakash, 2005; Zutshi\&Sohal, 2003).

The ISO 14000 series of standards are promoted as generic standards, meaning that they may be applied in any industry, in any nation (Christini et al., 2004; Curkovic et al., 2005; Ghisellini \& Thurston, 2005; Watson \& Emery, 2004; Zhang et al., 2000).

The international environmental management standards provide a means to ensure the performance of environmental management systems by integrating environmental protection criteria to performance criteria of the organization at every level. In addition, they provide a framework to direct the use of organizational resources to the full breadth of actual and potential environmental impacts through reliable management processes.

Certification with the standards also ensures transparency, and confirms commitment and performance of the organization providing market differentiation for those who satisfy the criteria and recognition as a reward to those willing to meet them. Because of their voluntary nature, the environmental management standards are based on self adjustment to continuous improvement of environmental performance through auditing and reviewing processes.

Within the entire series, the most well known ISO 14001 standard specifies the actual requirement for an EMS. An organization can be certified by an external certification authority against the ISO 14001 standard. The purpose of an EMS is clearly to bring a firm into alignment with its environmental policy and to demonstrate this to others (ISO, 1996). ISO 14001 certified EMS could be characterized in terms of its policy, goals, objectives, organizational structure, assigned responsibilities, procedures and operations, management review, and various methodologies.

To gain accreditation to the standard, organizations must have in place a framework by which they can understand, prioritize and address their environmental impacts. The emphasis is not only managing those impacts but also measuring them, accounting for them, reporting on them to stakeholders, and having those reports externally reviewed and verified (Goodman \& Stanger, 2002).

ISO 14000 assists the management obligations of environmental aspects and its implication to international trade and competition pushes strongly companies to participate early in the certification process (Begley, 1995).

The use of ISO 14000 standards is justified by four reasons:

(1) Improvement of managing environmental responsibility;

(2) Use as an alternative to command and control regulations;

(3) Improve community confidence; and

(4) Meet customer requirements (Mullin \& Sissell, 1995).

\section{Methods}

The model used for the identification of significant environmental impacts was an adapted input/output analysis recommended by the USEPA, 2000, and scenario analysis of Gray and Larson, 2008; Chapman, 1997. This was based on the principles of the risk assessment technique which is widely used in environmental, health and safety risk analysis. Mckim, 1992, defined risk as "an uncertainty associated with any outcome". This implies that the risk-based approaches focus on the negative impacts and their prevention (Hokstad \& Steiro, 2006). As such, the 
proposed approach places emphasis on the potential negative environmental impacts of an organization's activities and how they can be reduced or even prevented.

Gray and Larson 2008, specifies four main steps in the risk management process: risk identification, risk assessment, risk response development and risk response control. This study adapts the first two steps into environmental context and further introduces two additional steps to identify significant environmental impacts of operations.

\section{Results}

\subsection{Proposed Framework for Significant Environmental Impacts Identification}

In this section, the proposed framework is presented. The framework is divided into four main steps intended to be a continual process for the identification of significant environmental impacts as presented in figure 1 . In the proposed model, four main steps have been outlined:

Step 1: Environmental Aspects Identification; Step 2: Environmental Risk Assessment; Step 3: Environmental Risk Profiling; and Step 4: Environmental Risk Threshold Values.

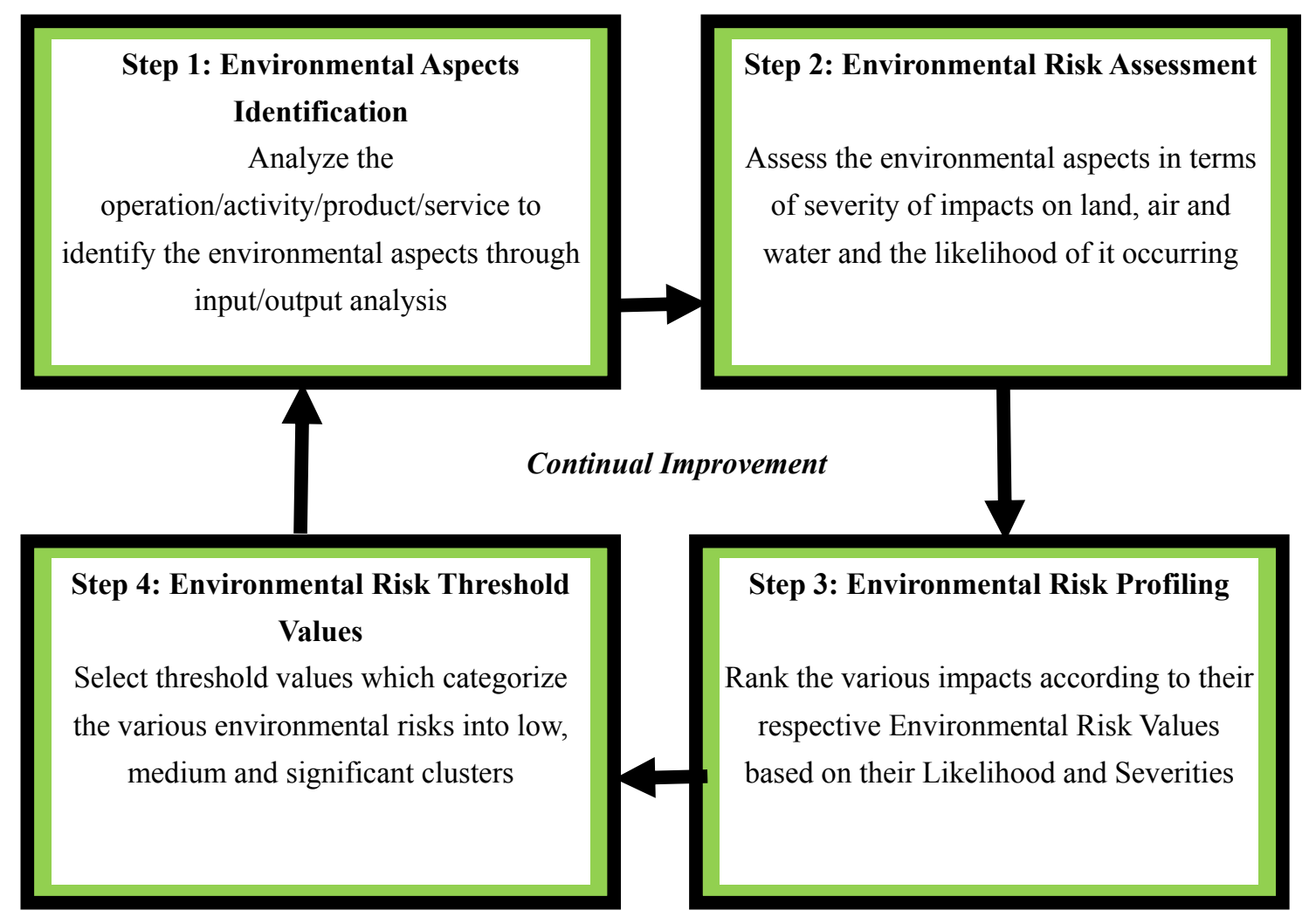

Figure 1. Proposed framework for significant environmental impacts identification

\subsubsection{Step 1: Environmental Aspects Identification}

In the proposed model, the first step is presented as, Environmental Aspects Identification: "This is how the organization's activities, products and services interact with the environment". This is achieved using the concepts of process maps or flow charts that identify the basic manufacturing and supporting operations, as well as the respective input/output of all these operations as recommended by the USEPA 2000. A schematic input/output diagram such as the one in figure 2 can be used to understand the environmental aspects of the organization's activities, processes, products or services. These diagrams assist the organization undertaken the environmental aspects identification to identify whatever is going into the process (inputs) as well as what its products (outputs) are. Based on this, the organization will be in the position to identify all the inefficiencies in resource use (water, energy, materials, etc) as well as waste products (pollution) emanating from the process to air, water, land/soil, personnel, etc. This information is used to feed into the second step of the process. 


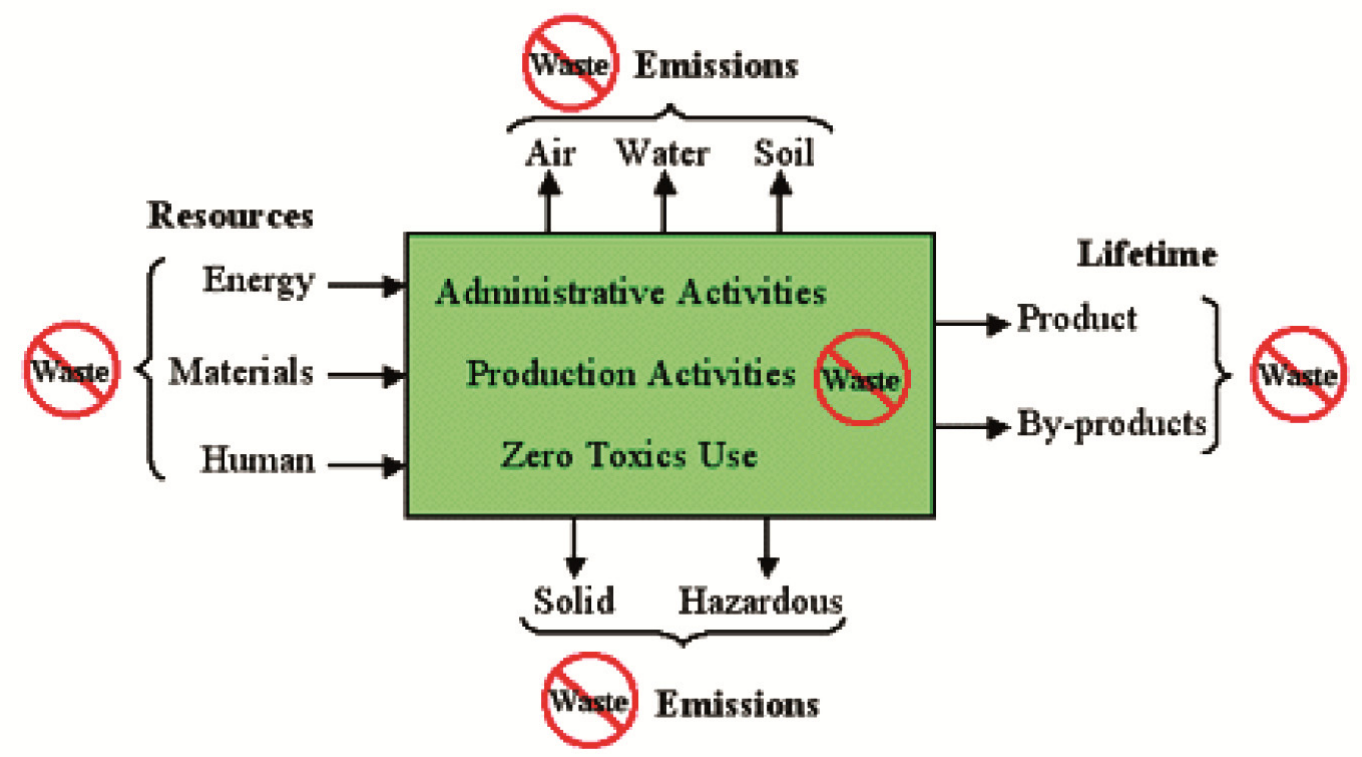

Figure 2. Zero waste strategy input-output diagram

Source: Zero Waste Alliance: http://www.zerowaste.org/case.htm

\subsubsection{Step 2: Environmental Risk Assessment}

In step two, the significance of these environmental aspects identified in step one are assessed based on the likelihood of their occurrence in the process as well as their consequences or impacts on the environmental media. The product of the likelihood and the consequence of their occurrence would result in a risk value as suggested by Chapman, 1997 and Khan and Haddara, 2003. As usual the environmental media of importance are; emissions to air, water pollution and use, energy (Berkhout et al., 2001), effect on soil/land, worker exposure, and natural resource use.

\subsubsection{Assessing the Likelihood and Consequence}

This sub-step which presents the probabilities and severities on a 5-point scale were adapted and modified after Gray and Larson, 2008. These respective scales are presented in Table 1.

Table 1. Likelihood and severity scale

\begin{tabular}{|c|c|c|c|}
\hline Scale & Likelihood & Scale & Severity \\
\hline 1 & $\begin{array}{l}\text { Very Unlikely: expect one occurrence or less } \\
\text { every month; }\end{array}$ & 1 & $\begin{array}{l}\text { Very low: the impact will not cause noticeable } \\
\text { damage to the environment; }\end{array}$ \\
\hline 2 & $\begin{array}{l}\text { Unlikely: expect one occurrence every three } \\
\text { weeks; }\end{array}$ & 2 & $\begin{array}{l}\text { Low: the impact will cause a damage that can } \\
\text { be reversed naturally; }\end{array}$ \\
\hline 3 & $\begin{array}{l}\text { Fairly Likely: expect one or more occurrences } \\
\text { two weeks; }\end{array}$ & 3 & $\begin{array}{l}\text { Moderate: the impact will cause moderate } \\
\text { damage on the environment; }\end{array}$ \\
\hline 4 & $\begin{array}{l}\text { Likely: expect one or more occurrence every } \\
\text { week; }\end{array}$ & 4 & $\begin{array}{l}\text { High: the impact will cause high damage on the } \\
\text { environment; }\end{array}$ \\
\hline 5 & $\begin{array}{l}\text { Very Likely: expect one or more occurrence } \\
\text { every day; }\end{array}$ & 5 & $\begin{array}{l}\text { Very high: the impact will cause very high } \\
\text { permanent damage on the environment; }\end{array}$ \\
\hline
\end{tabular}

During this sub-step, the respective inputs and outputs of the various processes are subjected to a detail environmental risk assessment using the likelihood and severity scales presented in table 1 to complete table 2 . Taking a glance through table 2 from left to right within the same row, columns one, two and three present the 
inputs/outputs, aspects and impacts of these aspects respectively. In the fourth column, the likelihood for these impacts to occur is documented using the likelihood scale in table 1. Columns five to ten presents the severities of these impacts to the respective environmental media likely to be affected. These severities are also assessed using the severity scales presented in table 1. In column eleven, the total sum (composite) of all these scores are presented. Composite severities for each aspect identified are also converted to a 5-point scale by summing up all the severities divided by thirty (30), multiplied by five (5) in column twelve. This then becomes the composite severity that is multiplied by the probability or likelihood to get the risk value for this aspect in column thirteen.

Table 2. Summarizes the results of step two in the significant environmental impacts identification

\begin{tabular}{|c|c|c|c|c|c|c|c|c|c|c|c|c|c|c|}
\hline \multicolumn{15}{|c|}{ Environmental Risk Assessment matrix } \\
\hline \multirow[b]{2}{*}{ 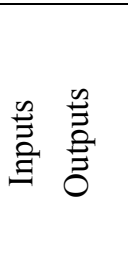 } & \multirow[b]{2}{*}{ 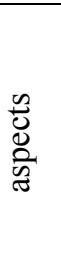 } & \multirow[b]{2}{*}{$\begin{array}{l}\mathscr{n} \\
\tilde{U} \\
\stackrel{\Xi}{E}\end{array}$} & \multirow[b]{2}{*}{ 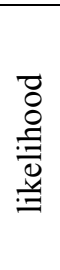 } & \multicolumn{6}{|c|}{ Impact on } & \multirow{2}{*}{$\frac{\stackrel{\infty}{\Xi}}{\frac{\mathscr{a}}{0}}$} & \multirow{2}{*}{ 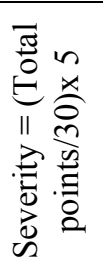 } & \multirow{2}{*}{ 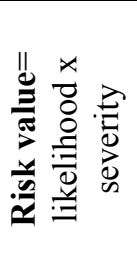 } & \multirow{2}{*}{ 䒿 } & \multirow{2}{*}{ : } \\
\hline & & & & 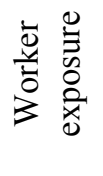 & $\overline{\bar{\delta}}$ & 齐 & 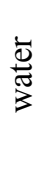 & 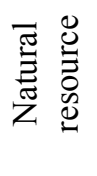 & क્ટે & & & & & \\
\hline \multicolumn{15}{|c|}{ Activity/product/service } \\
\hline \multicolumn{15}{|l|}{ Energy } \\
\hline \multicolumn{15}{|l|}{ Materials } \\
\hline Human & & & & & & & & & & & & & & \\
\hline
\end{tabular}

\subsubsection{Step 3: Environmental Risk Profiling}

During this stage, a simplified version of table 2 is developed by extracting columns, one, two, three, four and fourteen into table 3 . Table 3 , is then profiled (ranked) using the values in column fourteen with the highest value at the top followed by the next and so on. In Table 3, the first column is labeled rank, indicating the positions of the various impacts based on their environmental risk values. The information in columns two to six are basically those extracted from table 2 . The end result of table 3 is a complete profile containing all the environmental impacts in an order with the most risky impact on top with the less risky at the bottom. See table 3 for the details in the environmental risk profile.

Table 3. Environmental risk profile

\begin{tabular}{|c|c|c|c|c|c|c|}
\hline Rank & $\begin{array}{l}\text { Input - } \\
\text { Output }\end{array}$ & Aspects & Impacts & Likelihood & Severity & Environmental Risk \\
\hline 1 & & & & & & \\
\hline 2 & & & & & & \\
\hline 3 & & & & & & \\
\hline 4 & & & & & & \\
\hline 5 & & & & & & \\
\hline $\mathrm{n}$ & & & & & & \\
\hline
\end{tabular}

\subsubsection{Step 4: Environmental Risk Threshold Values}

This is the last step in the process which categorizes the risk profile in table three into impacts that are significant and insignificant. Here, threshold values such as the ranges adapted by Gray and Larson, 2008 can be used to summarize table 3 into three key categories; minor, moderate and major environmental risks. Based on this, table 4 is developed which presents the risk profile into three main categories:

- 11 - 25 High/major environmental risks; Red Zone; 
- 5-10 Moderate environmental risks; Yellow Zone and

- 1 - 4 Minor/Low environmental risks; Green Zone.

Table 4. Minor, moderate and major environmental risks

\begin{tabular}{|c|c|c|c|c|c|}
\hline Rank & $\begin{array}{l}\text { Input - } \\
\text { Output }\end{array}$ & Aspects & Likelihood & Severity & Environmental Risk \\
\hline 1 & & & Major/High & & \\
\hline 2 & & & Environmental Risk Zones & & $11-25$ \\
\hline 3 & & & Moderate Environmental & & \\
\hline 4 & & & Risk Zones & & $5-10$ \\
\hline 5 & & & Minor/Low & & \\
\hline $\mathrm{n}$ & & & Environmental Risk Zones & & $1-4$ \\
\hline
\end{tabular}

\subsection{Application of the Proposed Framework in the Mining Sector: Loading and Hauling}

In this section, the framework proposed has been applied in the mining sector to ensure the ease of its applicability. One key activity in the mining process that was chosen was the hauling activity. This activity was chosen because in a typical surface mine, this activity is of high importance as far as productivity is concerned. Loading is the process in which the in-situ material is transferred from the loading equipment into trucks after blasting, while hauling is basically how the loaded material is transported from the pit to either the waste dump or the Run-of-Mine (ROM) Pad.

To effectively apply the framework, there is the need to go through the entire four (4) step process prescribed in the model, viz.:

Step 1: Environmental Aspects Identification;

Step 2: Environmental Risk Assessment;

Step 3: Environmental Risk Profiling; and

Step 4: Environmental Risk Threshold Values.

\subsubsection{Step 1: Environmental Aspects Identification}

As recommended in the model, during this step, there is the need to understand, what really goes into every activity (inputs) and what the products (outputs) are. The model suggests a detail input/output diagram as presented in figure 2 previously. This is presented in figures 3 and 4 . Figure 4 presents the input-output diagram for the hauling operation. 


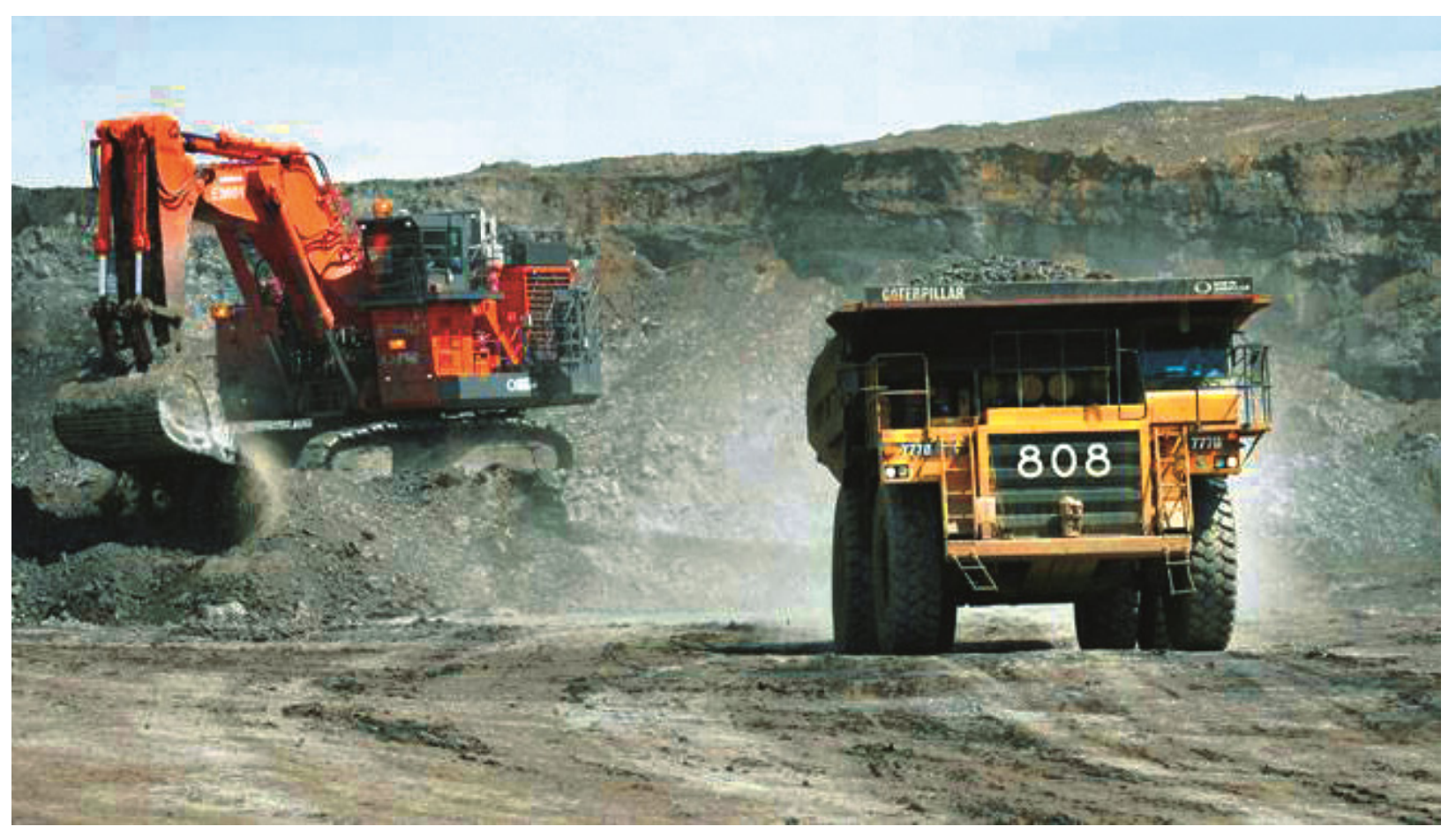

Figure 3. Haul truck carrying a full load drives away from an excavator

A haul truck carrying a full load drives away from a mining shovel at the Shell Albian Sands oilsands mine near Fort McMurray. (JEFF McINTOSH / CP). Source: Heralds Opinions: Paul Ruggles http://thechronicleherald.ca/opinion/87831-good-planets-hard-to-find-let-s-take-care-of-ours

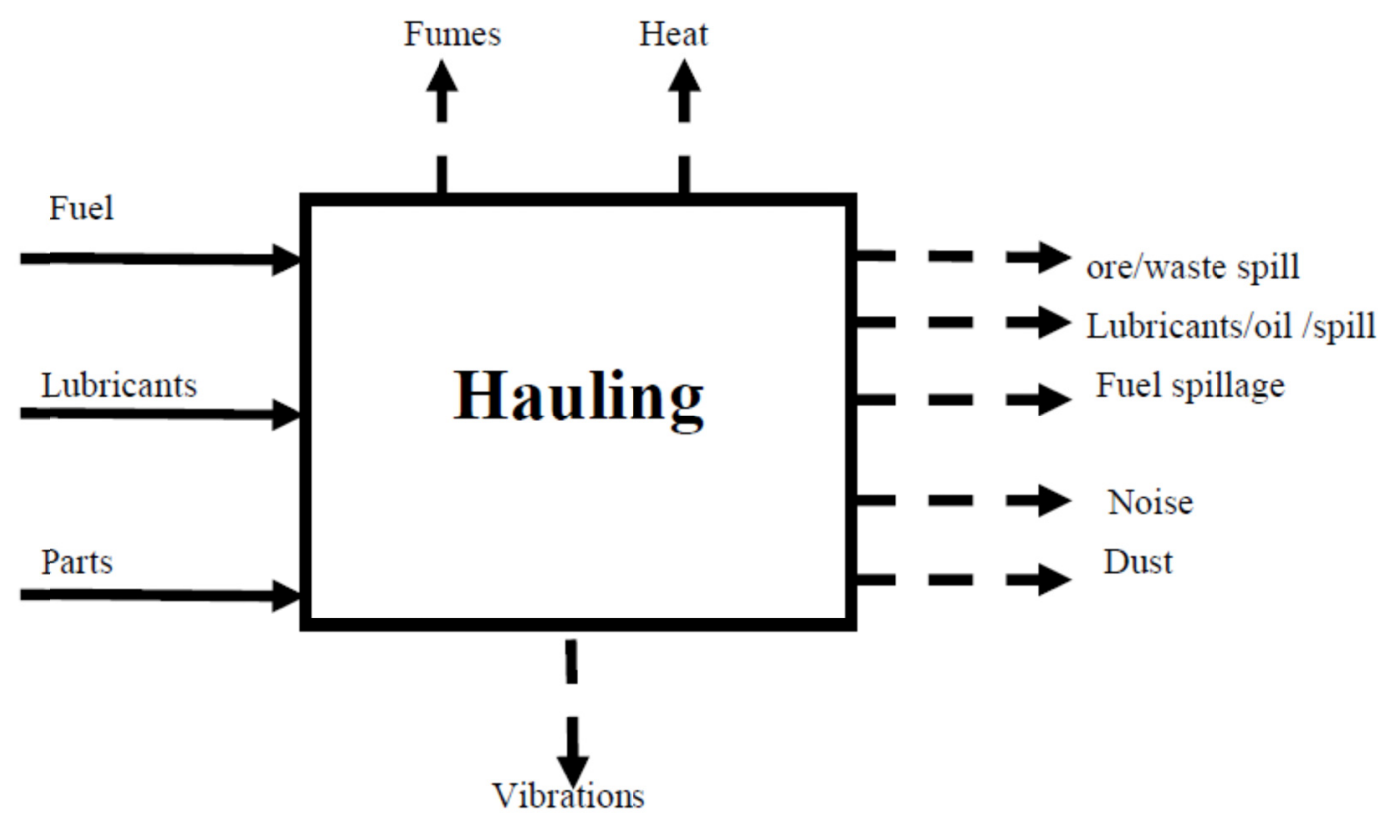

Figure 4. Environmental aspects identification: input-output diagram for the moving loaded truck in figure 3

\subsubsection{Step 2: Environmental Risk Assessment}

As recommended in the model, in step two, the significance of these environmental aspects identified in step one are assessed based on the likelihood of them occurring in the process as well as their consequences or impacts on the environmental if they really occurs. The product of their likelihood and the consequence of their occurrence would result in the severity of the risk. Table 5 presents the environmental assessment matrix showing the various inputs and outputs, the likelihood, and the environmental media affected by these impacts. It further 
presents how the assessment is done to identify those that are significant.

Table 5. Significant environmental impacts identification

\section{Environmental Risk Assessment matrix}

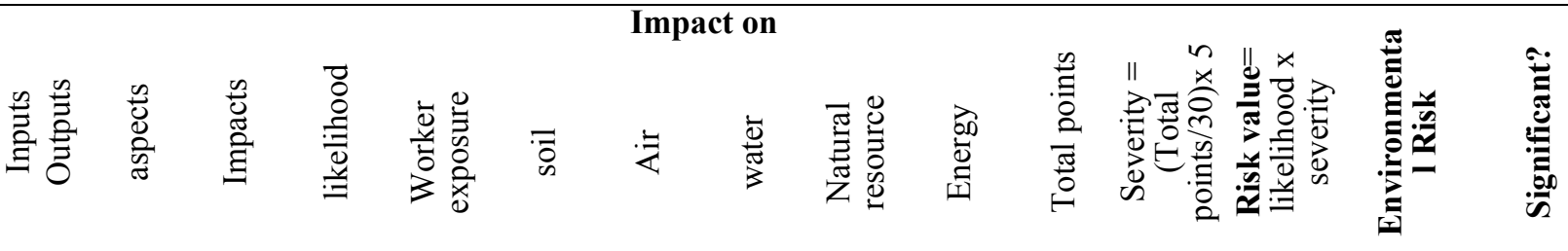

\begin{tabular}{|c|c|c|c|c|c|c|c|c|c|c|c|c|c|c|}
\hline \multicolumn{15}{|c|}{ Activity/product/service } \\
\hline Fuel & Fuel & NRU* & 5 & 1 & 1 & 1 & 1 & 4 & 4 & 12 & 2 & 10 & 10 & NO \\
\hline $\begin{array}{l}\text { Lubri } \\
\text { cants }\end{array}$ & $\begin{array}{l}\text { Lubri } \\
\text { cants }\end{array}$ & NRU & 3 & 1 & 1 & 1 & 1 & 4 & 4 & 12 & 2 & 6 & 6 & NO \\
\hline Parts & Parts & NRU & 1 & 1 & 2 & 1 & 2 & 2 & 2 & 10 & $1.6 \sim 2$ & 2 & 2 & NO \\
\hline $\begin{array}{c}\text { Fume } \\
\mathrm{s}\end{array}$ & Color & $\begin{array}{c}\text { Air } \\
\text { Pollu. }\end{array}$ & 3 & 2 & 1 & 4 & 2 & 1 & 3 & 13 & $2.1 \sim 2$ & 6 & 6 & NO \\
\hline Heat & Heat & $\mathrm{HR}^{* *}$ & 5 & 2 & 1 & 3 & 1 & 1 & 3 & 11 & $1.8 \sim 2$ & 10 & 10 & NO \\
\hline $\begin{array}{c}\text { Vibrat } \\
\text { ions }\end{array}$ & $\begin{array}{c}\text { Vibrat } \\
\text { ions }\end{array}$ & $\mathrm{HR}$ & 5 & 4 & 1 & 1 & 1 & 1 & 2 & 10 & $1.6 \sim 2$ & 10 & 10 & NO \\
\hline $\begin{array}{c}\text { Ore } \\
\text { waste } \\
\text { spill }\end{array}$ & Waste & $\begin{array}{c}\text { Equip } \\
\text { ment }\end{array}$ & 2 & 1 & 1 & 1 & 2 & 1 & 1 & 7 & $1.2 \sim 1$ & 2 & 2 & NO \\
\hline $\begin{array}{c}\text { Oil } \\
\text { spill }\end{array}$ & Oil & $\begin{array}{c}\text { Water } \\
\text { Soil }\end{array}$ & 2 & 2 & 2 & 1 & 3 & 1 & 2 & 11 & $1.8 \sim 2$ & 4 & 4 & NO \\
\hline $\begin{array}{l}\text { Fuel } \\
\text { spill }\end{array}$ & Fuel & $\begin{array}{c}\text { Water } \\
\text { Soil }\end{array}$ & 2 & 2 & 2 & 1 & 3 & 1 & 2 & 11 & $1.8 \sim 2$ & 4 & 4 & NO \\
\hline Noise & Noise & HR & 5 & 4 & 1 & 2 & 1 & 1 & 1 & 10 & $1.6 \sim 2$ & 10 & 10 & NO \\
\hline Dust & Dust & $\begin{array}{l}\text { Veget } \\
\text { ation } \\
\& \text { HR }\end{array}$ & 5 & 4 & 3 & 5 & 4 & 1 & 3 & 20 & $3.3 \sim 3$ & 15 & 15 & YES \\
\hline
\end{tabular}

* Natural Resource Use

** Human Resource

4.2.3 Step 3: Environmental Risk Profiling

During this step, a complete profile containing all the environmental impacts in an order with the most risky impact on top and with the less at the bottom. The risk profile as recommended in table 3 previously in the proposed framework is presented in table 6 . 
Table 6. Environmental risk profile of the hauling activity in a mine

\begin{tabular}{|c|c|c|c|c|c|c|}
\hline Rank & $\begin{array}{l}\text { Input - } \\
\text { Output }\end{array}$ & Aspects & Impacts & Likelihood & Severity & $\begin{array}{c}\text { Environmental } \\
\text { Risk }\end{array}$ \\
\hline 1 & Dust & Dust & $\begin{array}{c}\text { Air Pollution \& } \\
\text { HR }\end{array}$ & 5 & 3 & 15 \\
\hline 2 & Noise & Noise & HR & 5 & 2 & 10 \\
\hline 3 & Vibrations & Vibrations & HR & 5 & 2 & 10 \\
\hline 4 & Heat & Heat & HR & 5 & 2 & 10 \\
\hline 5 & Fuel & Fuel & NRU & 5 & 2 & 10 \\
\hline 6 & Fumes & $\begin{array}{l}\text { Change of air } \\
\text { color }\end{array}$ & Air and HR & 3 & 2 & 6 \\
\hline 7 & Lubricants & Lubricants & NRU & 3 & 2 & 6 \\
\hline 8 & Oil Spill & Oil & Soil/Water Poll & 2 & 2 & 4 \\
\hline 9 & Fuel Spill & Fuel & Soil/Water Poll & 2 & 2 & 4 \\
\hline 10 & Ore/waste spill & Waste & Equipment & 2 & 1 & 2 \\
\hline 11 & Parts & Parts & Waste & 1 & 2 & 2 \\
\hline
\end{tabular}

\subsubsection{Step 4: Environmental Risk Threshold Values}

This is the last step in the process. This categorizes the risk profile in table 6 into impacts that are significant and insignificant. The threshold values such as the ranges recommended previously have been used to categorize table 6 into three key categories, minor, moderate and major environmental risks. See table 7 for these respective categories.

- $\quad 11-25 \mathrm{High} / \mathrm{major}$ environmental risks; Red Zone.

- 5-10 Moderate environmental risks; Yellow Zone and

- 1 - 4 Minor/Low environmental risks; Green Zone.

From table 7, it can be deduced that dust from the hauling operation is the aspect with the most significant environmental impact. 
Table 7. Minor, moderate and major environmental risks

\begin{tabular}{|c|c|c|c|c|c|c|c|}
\hline Rank & $\begin{array}{l}\text { Input - } \\
\text { Output }\end{array}$ & Aspects & Impacts & Likelihood & Severity & $\begin{array}{c}\text { Environmental } \\
\text { Risk }\end{array}$ & RISK \\
\hline 1 & Dust & Dust & $\begin{array}{c}\text { Air } \\
\text { Pollution \& } \\
\text { HR }\end{array}$ & 5 & 3 & 15 & $\begin{array}{c}\text { High } \\
\text { Environmental } \\
\text { Risk Zone }\end{array}$ \\
\hline 2 & Noise & Noise & HR & 5 & 2 & 10 & \\
\hline 3 & Vibrations & Vibrations & HR & 5 & 2 & 10 & Medium \\
\hline 4 & Heat & Heat & HR & 5 & 2 & 10 & Environmental \\
\hline 5 & Fuel & Fuel & NRU & 5 & 2 & 10 & Risk \\
\hline 6 & Fumes & $\begin{array}{l}\text { Change of } \\
\text { air color }\end{array}$ & Air and HR & 3 & 2 & 6 & Zone \\
\hline 7 & Lubricants & Lubricants & NRU & 3 & 2 & 6 & \\
\hline 8 & Oil Spill & Oil & $\begin{array}{l}\text { Soil/Water } \\
\text { Poll }\end{array}$ & 2 & 2 & 4 & $\begin{array}{c}\text { Minor } \\
\text { Environmental }\end{array}$ \\
\hline 9 & Fuel Spill & Fuel & $\begin{array}{l}\text { Soil/Water } \\
\text { Poll }\end{array}$ & 2 & 2 & 4 & Risk \\
\hline 10 & $\begin{array}{c}\text { Ore/waste } \\
\text { spill }\end{array}$ & Waste & Equipment & 2 & 1 & 2 & EOIV \\
\hline 11 & Parts & Parts & Waste & 1 & 2 & 2 & \\
\hline
\end{tabular}

\section{Conclusions}

The study sought out to propose a framework for the identification of significant environmental impacts of manufacturing and service operations. In all, four key steps have been proposed. These are:

- Step 1: Environmental Aspects Identification;

- Step 2: Environmental Risk Assessment;

- Step 3: Environmental Risk Profiling; and

- Step 4: Environmental Risk Threshold Values.

To enable the framework to be easily applicable, the author applied it to a typical hauling operation in a mine. Based on the threshold values selected, dust was identified as the significant environmental impact of every hauling activity.

\section{Implications of the Study}

This study suggest that some of the techniques used to assess the risks associated with a typical project can also be adapted to assess the risk posed to the environment from manufacturing and service operations. It is important that operations managers understand all the inputs needed for all activities, the conversion processes as well as the by-products, especially pollutants resulting from each activity to enable them assess their impacts on the environment. In assessing the impacts of these inputs and outputs, it is also important to take into consideration, their effect on air, workers, water, soil/land and natural resource use.

\section{Limitations and Future Research Directions}

This study only considered only six key environmental factors that can be affected by manufacturing and service operations. Apart from these factors, there is also the need to look at other factors. Future studies can also look at how the model can be applied to the entire mining sector as well as other sectors of the economy especially the emerging oil and gas sectors.

\section{References}

Aven, T., \& Kristensen, V. (2005). Perspectives on risk: review and discussion of the basis for establishing unified and holistic approach.Reliability Engineering and System Safety, 90(1), 1-14. 
http://dx.doi.org/10.1016/j.ress.2004.10.008

Babakri, K. A., Bennett, R. A., Rao, S., \& Franchetti, M. (2004). Recycling performance of firms before and after adoption of the ISO 14001 standard.Journal of Cleaner Production, 12, 633-637. http://dx.doi.org/10.1016/S0959-6526(03)00118-5

Ball, D. J. (2002). Environmental risk assessment and the intrusion of bias.Environment International, 28(6), 529-544. http://dx.doi.org/10.1016/S0160-4120(02)00061-2

Begley, R. (1995). Environmental ISO standards adds to management tasks: environmental systems get new scrutiny.Chemical Week, 157, 45.

Berkhout, F., Hertin, J., Azzone, G., Carlens, J., Drunen, M., Jasch, C. ... Wolf, O. (2001).Measuring the Environmental Performance of Industry, Final Report of Project MEPI (ENV4-CT97-0655), Environment and Climate Research Programme, European Commission (EC), Brussels.

Blackman, A., \& Guerrero, S. (2012). What drives voluntary eco-certification in Mexico? Journal of Comparative Economics, 40(2), 256-268.http://dx.doi.org/10.1016/j.jce.2011.08.001

Chapman, C. B. (1997). Project risk analysis and management - PRAM the generic process.International Journal of Project Management, 15(5), 273-281.http://dx.doi.org/10.1016/S0263-7863(96)00079-8

Chavan, M. (2005).An appraisal of environmental management systems: A competitive advantage for small $\begin{array}{lllll}\text { business.Management of } & \text { Environmental }\end{array}$ http://dx.doi.org/10.1108/14777830510614321

Chaverri, R. L. (1999). Development of environmental performance indicators: the case of fish canning plants.Master's thesis, International Institute for Industrial Environmental Economics, Lund University, Lund.

Christini, G., Fetsko, M., \& Hendrickson, C. (2004).Environmental management systems and ISO 14001 certification for construction firms.Journal of Construction Engineering and Management, 130(3), 330-336. http://dx.doi.org/10.1061/(ASCE)0733-9364(2004)130:3(330)

Christou, M., \& Amendale, A. (1998).How lessons learned from exercises can improve the quality of risk studies. In A. Mosleh, \& R. A. Bari (Eds.), Proceedings of the 4th International Conference on Probabilistic Safety Assessment and Management (PSAM). New York, NY.

Curkovic, S., Sroufe, R., \& Melnyk, S. (2005). Identifying the factors which affect the decision to attain ISO 14000. Energy, 30, 1387-1407. http://dx.doi.org/10.1016/j.energy.2004.02.016

Diakaki, C., Grigoroudis, E., \& Stabouli, M. (2006).A risk assessment approach in selecting environmental performance indicators.Management of Environmental Quality: An International Journal, 17(2), 126-139 http://dx.doi.org/10.1108/14777830610650456

EPA. (n. d.). United States Environmental Protection Agency (USEPA). Retrieved February 1, 2014, from http://www.epa.gov/nrmrl/std/lca/resources.html

Everett, J., \& Neu, D. (2000). Ecological modernisation and the limits of environmental Accounting. Accounting Forum, 24, 5-29. http://dx.doi.org/10.1111/1467-6303.00027

Fiksel, J. (2002). Key Performance Indicators, Substudy 5, World Business Council for Sustainable Development (WBCSD), report of the project towards a sustainable cement industry, Bergen.

Fisher, R. M. (2003). Applying ISO 14001 as a business tool for campus sustainability: A case study from New Zealand. International Journal of Sustainability in Higher Education, 4(2), 138-150. http://dx.doi.org/10.1108/14676370310467159

Ghisellini, A., \& Thurston, D. L. (2005).Decision traps in ISO 14001 implementation process: case study results from Illinois certified companies. Journal of Cleaner Production, 13, 763-777. http://dx.doi.org/10.1016/j.jclepro.2004.02.042

Goodman, S., \& Stanger, C. (2002). Guide to Environmental Management Law and Practice 2002. Workplacelaw Network, Cambridge, pp. 51-55.

Gray, R. (2010). Is accounting for sustainability actually accounting for sustainability and how would we know? An exploration of narratives of organisations and the planet.Accounting, Organizations and Society, 35(1), 47-62. http://dx.doi.org/10.1016/j.aos.2009.04.006 
Gray, C. F., \& Larson, E. W. (2008). Project Management, the managerial process. McGraw-Hill/Irwin.

Hamel, G., \& Prahalad, C. K. (1994).Competing for the Future. Harvard Business School Press, Boston, MA, pp. 24-32.

Hannagan, T. (1998).Management: Concepts and practices.Financial Times, Pitman Publishing, pp. 567-569.

Hokstad, P., \& Steiro, T. (2006). Overall strategy for risk evaluation and priority setting of risk regulations.Reliability Engineering and System Safety, 91(1), 3575-3586. http://dx.doi.org/10.1016/j.ress.2004.11.014

Hunt, C. B., \& Auster, E. R. (1990). Proactive environmental management: Avoiding the toxic trap. Sloan Management Review, 31(2), 7-18.

International Organisation for Standardisation. (1999). ISO 14031 Environmental Management - Environmental Performance Evaluation - Standards and Guidelines, International Organisation for Standardisation, Geneva.

ISO. (2004). ISO14001 Environmental Management System - Requirements with Guidance for Use, International Standards Organisation, Geneva.

ISO. (n. d.). ISO 31000 - Risk management. Retrieved from http://www.iso.org/iso/home/standards/iso31000.htm

Jain, S., \& Pant, P. (2010). Environmental management systems for educational institutions: A case study of TERI University, New Delhi. International Journal of Sustainability in Higher Education, 11(3), 236-249. http://dx.doi.org/10.1108/14676371011058532

Jesson, J., \& Andersen, S. (1994). Introduction to management requirements and toolkits. Journal of Cleaner Production, 2(2), 95-99. http://dx.doi.org/10.1016/0959-6526(94)90006-X

Karrer-Ru“. (Ed.). (1998).Environmental Management Systems and Standards.Swiss Re America, New York, NY.

Khan, F. I., \& Haddara, M. M. (2003). Risk-based maintenance (RBM): A quantitative approach for maintenance/inspection scheduling and planning.Journal of Loss Prevention in the Process Industries, 16(6), 561-573. http://dx.doi.org/10.1016/j.jlp.2003.08.011

Kolluru, R., Bartell, S., Pitblado, R., \& Stricoff, S. (1996). Risk Assessment and Management Handbook: For Environmental, Health and Safety Professionals. McGraw-Hill, New York, NY.

Lalley, E. (1982). Corporate Uncertainty and Risk Management, Risk Management Society Publishing, New York, NY.

Llewellyn, G. (1998). Strategic risk assessment - prioritising environmental protection. Journal of Hazardous Materials, 61(1-3), 279-286. http://dx.doi.org/10.1016/S0304-3894(98)00133-2

Marimon, F., Casadesus, M., \& Heras, I. (2010).Certification intensity level of the leading nations in ISO 9000 and ISO 14000 standards. International Journal of Quality \& Reliability Management, 27(9), 1002-1020. http://dx.doi.org/10.1108/02656711011084800

Mauser, A. (2001). The Greening of Business, Environmental Management and Performance Evaluation: An Empirical Study in the Dutch Dairy Industry. Eburon Publishers, Delft.

Mckim, R. A. (1992). Risk management-back to basics. Cost Engineering, 34(12), 7-12.

Mullin, R., \& Sissel, K. (1995). Managers gear up for global standards. Chemical Week, 157(65).

Porter, M., \& van der Linde, C. (1995, September-October). Green and competitive: Ending the stalemate. Harvard Business Review, 121-134.

Potoski, M., \& Prakash, A. (2005). Green clubs and voluntary governance: ISO 14001 and firms' regulatory compliance. American Journal of Political Science, 49(2), 235-248. http://dx.doi.org/10.1111/j.0092-5853.2005.00120.x

Rahaman, A. S., Lawrence, S., \& Roper, J. (2004). Social and environmental reporting at the VRA: institutionalised legitimacy or legitimation crisis? Critical Perspectives on Accounting, 15(1), 35-56. http://dx.doi.org/10.1016/S1045-2354(03)00005-4

Shah, S. (2004). The role of facilities management. Essential Report, 35, 6-8.

Slater, D., \& Jones, H. (1999). Environmental risk assessment and the environment agency. Journal of Hazardous Materials, 65(1-2), 77-91. http://dx.doi.org/10.1016/S0304-3894(98)00256-8 
Tixier, J., Dusserre, G., Salvi, O., \& Gaston, D. (2002). Review of 62 risk analysis methodologies of industrial plants. Journal of Loss Prevention in the Process Industries, 15(4), 291-303. http://dx.doi.org/10.1016/S0950-4230(02)00008-6

Von Bahr, B., Hanssen, O. J., Vold, M., Pott, G., Stoltenberg-Hansson, E., \& Steen, B. (2003).Experiences of environmental performance evaluation in the cement industry: Data quality of environmental performance indicators as a limiting factor for benchmarking and rating.Journal of Cleaner Production, 11(7), 713-725. http://dx.doi.org/10.1016/S0959-6526(02)00126-9

Watson, M., \& Emery, A.R.T. (2004).Environmental management and auditing systems: The reality of

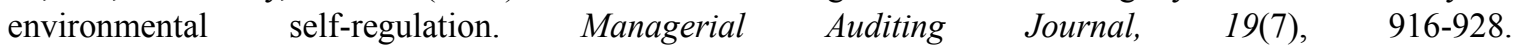
http://dx.doi.org/10.1108/02686900410549439

Whitelaw, K. (1997). ISO 14001 Environmental Systems Handbook. Butterworth-Heinemann, Oxford.

Zhang, Z. H., Shen, L. Y., Love, P. E. D., \& Treloar, G. (2000). A framework for implementing ISO 14001 in

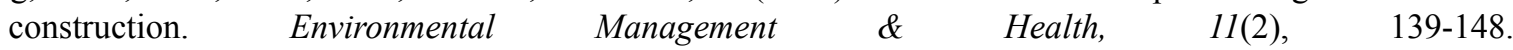
http://dx.doi.org/10.1108/09566160010321541

Zutshi, A., \& Sohal, A. (2003). Environmental management system auditing within Australasian companies.Managerial Auditing Journal, 18(8), 637-648. http://dx.doi.org/10.1108/02686900310495133

\section{Copyrights}

Copyright for this articleis retained by the author(s), with first publication rights granted to the journal.

This is an open-access article distributed under the terms and conditions of the Creative Commons Attribution license (http://creativecommons.org/licenses/by/3.0/). 